\title{
CUSTOMER LOYALTY TO BANK SERVICES: THE BIBLIOMETRIC ANALYSIS
}

\author{
Oleksii Dubina, Yana Us, Tetyana Pimonenko, and Oleksii Lyulyov
}

\begin{abstract}
Systematisation of literary sources on and approaches to solving the problem of enhancing customer loyalty indicated that scholars had contributed significantly to enriching the scientific research aimed at ensuring the effective long-term consumer interaction. Accordingly, the current paper aims at conducting the bibliometric analysis of publications on customer loyalty to banks institutions. The object of research is the scientific documents published in the biggest abstract database Scopus. The paper follows in the next logical sequence. Firstly, the authors search scientific studies indexed by Scopus database from 2000 to 2019 in the domain of customer loyalty. The document search was conducted in the following areas: the article title, abstract and keywords. Herewith, the combinations of keywords included: bank and customer; bank and loyalty, bank reputation and loyalty; bank confidence and loyalty; bank trust and loyalty; bank and customer; bank and communication strategy. With the irrelevant documents excepted and the duplicate ones eliminated, the determinate sample of documents investigated amounted for 2752 items. Secondly, the selected papers were visualised with VOSviewer software to build the network maps displaying the relationships among the keywords. Thus, the obtained results allowed describing the main directions in the scientific treatise on customer loyalty to banking as well as highlighting the scientific schools interested in exploring the investigated theme. The authors noted that the findings might be the base for future investigation on developing the communication strategies to increase customer loyalty to bank institutions.
\end{abstract}

Keywords: loyalty, bank, customer, confidence

JEL Classification: G21, D12, M3

Oleksii Dubina, Yana Us, Tetyana Pimonenko, and Oleksii Lyulyov

Virtual Economics, Vol. 3, No. 3, 2020 


\section{Authors:}

Oleksii Dubina

Sumy State University, Sumy, Ukraine

E-mail: liondan2011@gmail.com

https://orcid.org/0000-0003-1451-0450

\section{Yana Us}

Sumy State University, Sumy, Ukraine

E-mail:y.us@fem.sumdu.edu.ua

https://orcid.org/0000-0003-1451-0450

\section{Tetyana Pimonenko}

Sumy State University, Sumy, Ukraine

E-mail: tetyana pimonenko@econ.sumdu.edu.ua

https://orcid.org/0000-0001-6442-3684

\section{Oleksii Lyulyov}

Sumy State University, Sumy, Ukraine

E-mail: alex lyulev@econ.sumdu.edu.ua

https://orcid.org/0000-0002-4865-7306

Citation: Dubina, O., Us, Y., Pimonenko, T., \& Lyulyov, O. (2020). Customer Loyalty to Bank Services: The Bibliometric Analysis. Virtual Economics, 3(3), 52-66. https://doi.org/10.34021/ve.2020.03.03(3)

Received: January 15, 2020. Revised: March 12, 2020. Accepted: June 18, 2020.

(C) Author(s) 2020. Licensed under the Creative Commons License - Attribution 4.0 International (CC BY 4.0)

Oleksii Dubina, Yana Us, Tetyana Pimonenko, and Oleksii Lyulyov

Virtual Economics, Vol. 3, No. 3, 2020 


\section{Introduction}

Nowadays, the economic crisis developing due to the virus COVID-19 causes the necessity to strengthen the stability of financial institutions. In turn, the customer level of confidence in financial institutions is the determinant factor in providing their stable functioning (Lyulyov \& Shvindina, 2017). It worth noting that a retrospective analysis of banking industry's functioning in independent Ukraine has demonstrated the massive bank shutdown. Figure 1 shows the number of commercial banks decreased by approximately $60 \%$ in January 2020 compared to January 2008. The facts mentioned above resulted in reducing the customer confidence in the banks. Consequently, the banks are to change their communication strategies to earn customer loyalty and develop a reliable reputation.

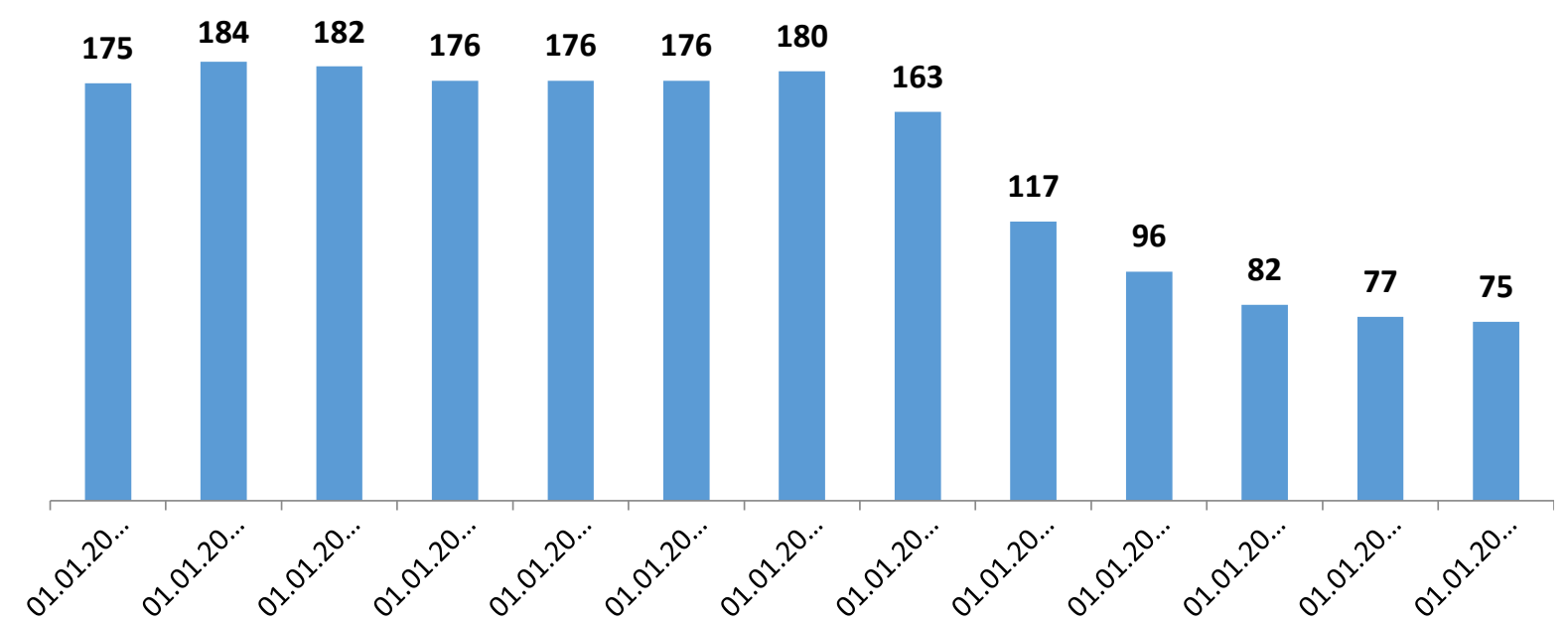

Figure 1. The dynamic of commercial banks' emergence in Ukraine from 2008 to 2020 Source: developed by the authors based on the data from the National Bank of Ukraine.

The analysis of scientific studies indicated the existence of some factors influencing the loyalty level of bank customers (Matute-Vallejo et al., 2011; Baumann et al., 2007). Thus, in the process of decision-making, the bank customers, first of all, pay attention to the level of a bank's reliability, history and reputation. Herewith, the highly-ranked banks always analyse the customer behaviour and changes in their preferences to react and adapt their management techniques operationally. Moreover, the obtained research result noted that bank reputation is one of the main factors that influence the level of customer loyalty.

Systematisation and summarisation of scientific studies in the investigated field allowed making a conclusion about the absence of the unique conventional technique to estimate the loyalty of the bank customers. In that context, it is appropriate to analyse and determine the "golden formula" of customer loyalty. This study aims to determine the impact factors on the level of customer loyalty to banks based on the analysis of the scientific schools comprehensively investigating customer loyalty to banks. At the same time, the banking system was considered as a vital part of the state activity. 


\section{The Literature Review}

An in-depth analysis of the literature background indicated the growing scientific interest in investigating customer loyalty to bank institutions (Chygryn et al., 2018; Bilan et al., 2019). Consequently, in the framework of the current article, the bibliometric analysis was conducted to structure the scientific background, to identify the main research directions and to find out the fundamental scientific schools studying this issue. In the study by Loveman (1998), the loyalty level to banks was considered in the view of customer and employee satisfaction. The author noted that the bank's financial performance was one of the determinate factors to increase the customer trust to a specific bank.

The researchers Bloemer J., de Ruyter K., and Peeters P. (Bloemer et al., 1998; Aurier \& N'Goala, 2010; Dzwigol et al., 2020) provided the complex analysis of the relationship between customer loyalty to banks and impact factors such as bank service quality, its position on the financial market and customer satisfaction. Several scientific papers (Ibragimov et al., 2019; Matsenko et al., 2011; Lyulyov \& Pimonenko, 2017; Sweeney \& Swait, 2008; Kwilinski, 2019; Kwilinski et al., 2020; Pająk et al., 2016; Tkachenko et al., 2019; Vishnevsky \& Kwilinski, 2019) aimed at analysing the brand of a particular bank and financial innovation. The authors used the economic base to prove that the bank brand played a significant role in increasing customer loyalty and trust. Some papers (Jones et al., 2002; Cooil et al., 2007; Chyhryn \& Scherbak, 2011) provided the findings on analysing the customer's profile to build the effective communicative strategy with the bank target group.

Casalo et al. (2008) described the concepts of customer loyalty and the effect of positive wordof-mouth regarding e-banking services. The findings of this research indicated the necessity to prioritise customer needs and simple customer interactions with e-bank services. The authors of another scientific paper (Han et al., 2008) built the integrative model to measure the multidimensional view of customer loyalty. The authors noted that the customer loyalty depended on the several factors such as: trust, service quality, customer satisfaction, bank friendship, etc.

\section{Methods}

In the frame of this article, achieving the main purpose necessitated implementing several steps. During the first step, the scientific papers on the investigated theme were searched in the Scopus database. Application of different sets of keywords combinations allowed selecting the most relevant articles to achieve the purpose of the current research. The document search was conducted in such fields as: Article title, Abstract and Keywords. Therefore, such combinations of keywords as "bank* AND customer* loyalty" resulted in 241 documents; "bank* AND loyalty" gave 1027 documents; "bank* reputation and loyalty" resulted in 38 papers; "bank* confidence and loyalty" - in 27, "bank* trust and loyalty" - in 228.; "bank* and customer*" - in 97; "bank* AND communication strategy*" - I 1115. Then, the period of documents' publication was restricted to that of $2000-2019$. Moreover, the irrelevant versions of keywords and double papers were extracted to make the sample more accurate. 
As a result, the determinate sample of investigated documents amounted to 2752 items. It is worth mentioning that the Boolean operator "AND" was used to find the documents which included both keywords in the article title or keywords of the article and the abstract. Furthermore, to save the specific phrases, the doubled quotes were applied. Herewith, the sign "*" allowed including the keywords which had the plural or different ending.

It is worth emphasising that the Scopus database is the largest database of abstracts presenting high-quality scientific documents. It allowed finding the permanent data, explore the new research, scientific journals, research in the investigated field. Thus, based on the Scopus data, the bibliometric analysis was on the consumer loyalty to the bank was carried out in the view of publication activity dynamics, the most cited authors, countries, affiliations and funding sponsors.

On the second step, the data of the documents selected were visualised with VoSviewer software. VOSviewer tool allowed creating the network maps based on combining the several documents formulated with the Scopus tools. Thus, the results allowed visualising the relationships among the keywords and allowed describing the main directions in the scientific treatise on customer loyalty to banks as well as highlighting the scientific schools interested in exploring the investigated theme.

Notably, the network maps consist of different sized circles, colours, and links. Herewith, the size of the circle means the number of published documents under the specific item. Furthermore, the bigger size of the circle means that more documents were presented with this keyword (Panchenko et al., 2020). Then, the colours allow identifying the particular cluster. The links provide information on the items' interactions. In turn, the distance between two circles shows the frequency of the item's appearance in the documents. The longer the distance is, the more times the items appear.

\section{Results and Discussion}

The result of analysing the publication activity in the Scopus database has revealed the growing number of scientific studies dedicated to investigating customer loyalty and building the bank reputation. In the framework of this article, 2752 scientific documents indexed by Scopus database were considered.

As showed in Figure 2, the publication activity on customer loyalty to bank institutions and its systems was increasing during the financial crises 2008-2009 and 2014-2015. Notably, the economic crises caused the outflow of customers and capitals. In turn, the interest is in investigating the determinative factors which influence on the customer solution to be loyal to the bank. 


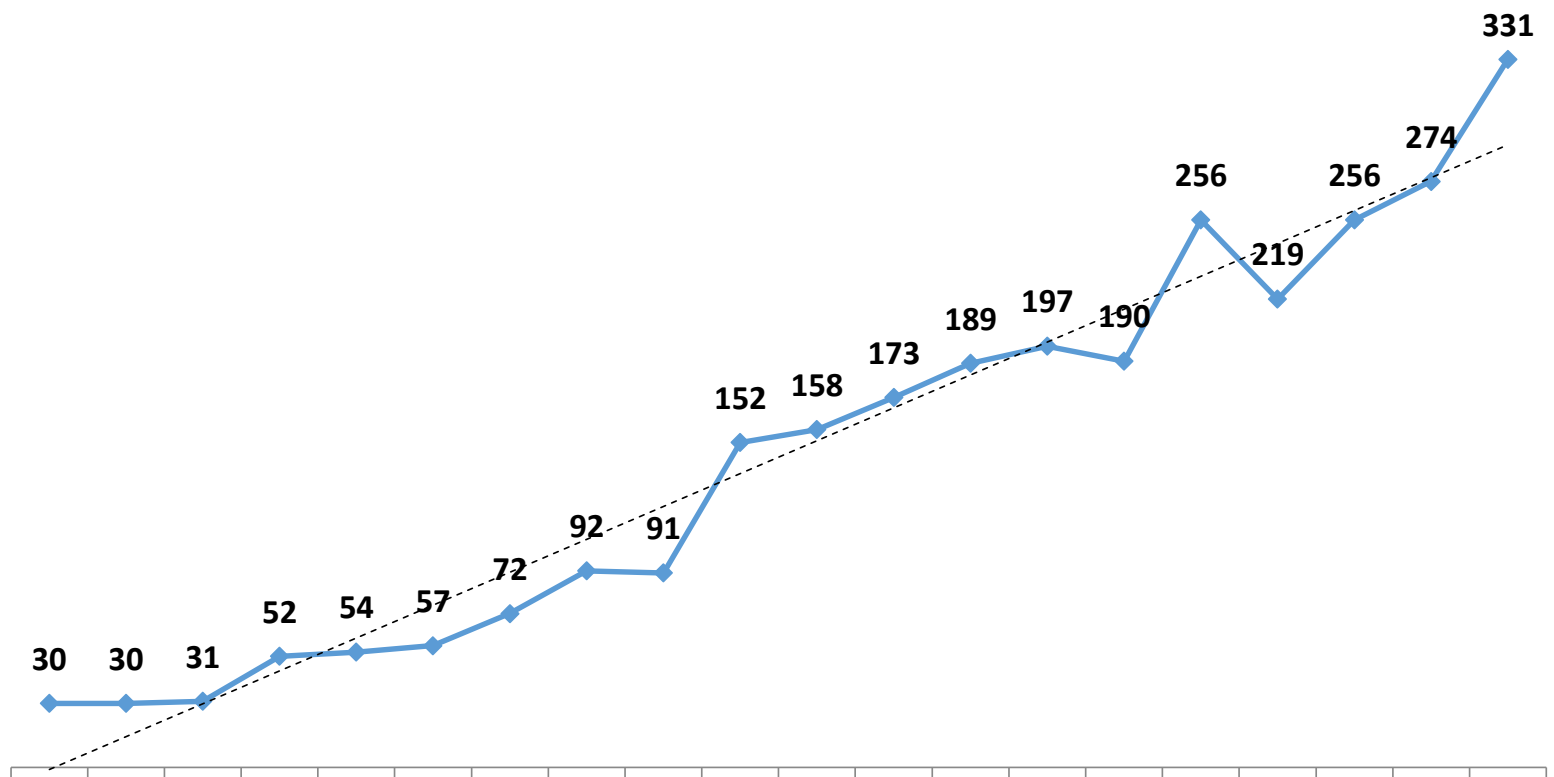

20002001200220032004200520062007200820092010201120122013201420152016201720182019

Figure 2. The Dynamic of Publication Activity on Customer Loyalty to Banks from 2000 to 2019 Source: developed by the authors based on the Scopus database.

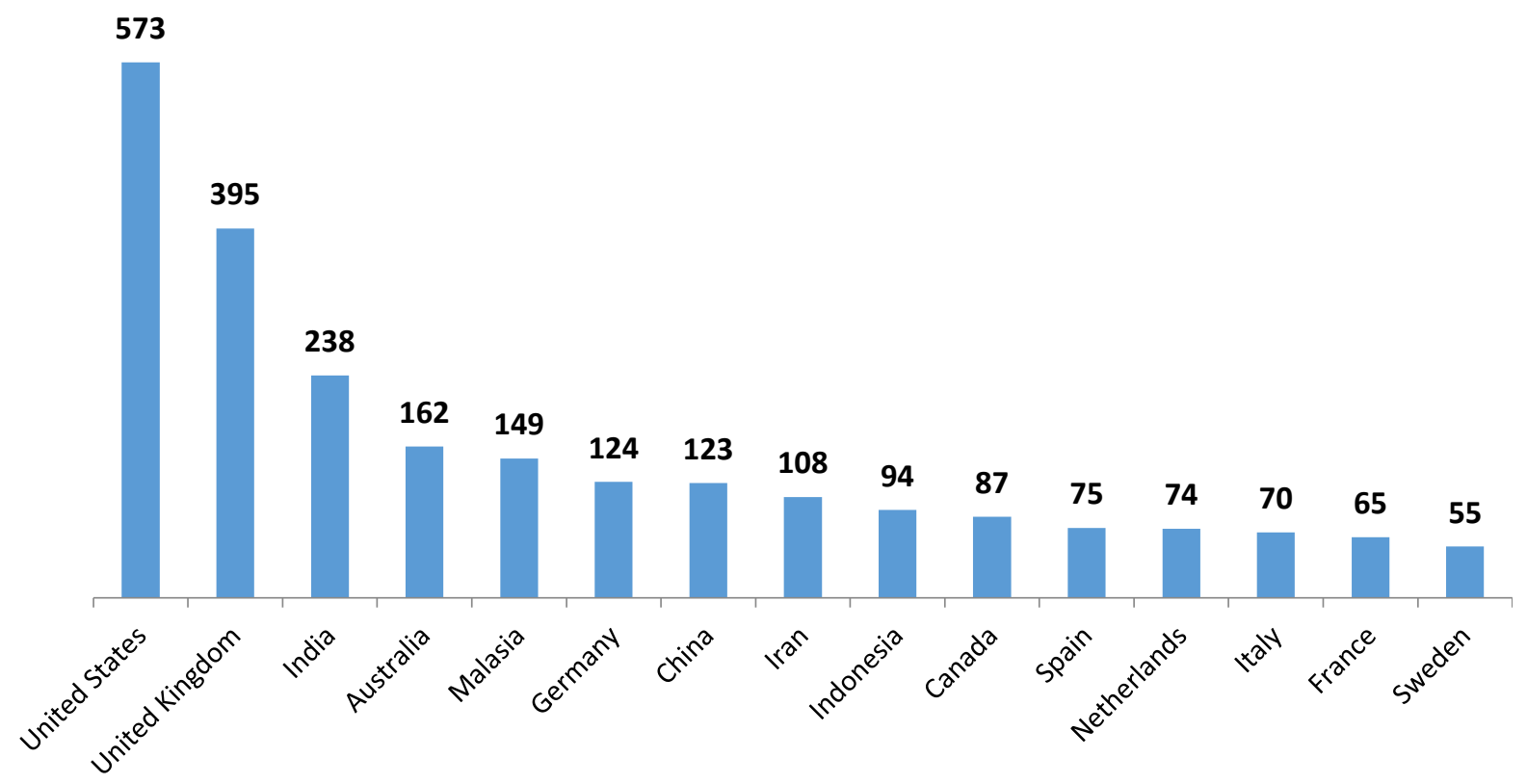

Figure 3. The Structure of Publication Activity on Customer Loyalty to Banks by Countries from 2000 to 2019

Source: developed by the authors based on the Scopus database.

According to Figure 3, the most significant share of documents dedicated to customer loyalty to bank institutions was published by researchers from the United States. Thus, the authors 
presented 573 scientific papers in the Scopus database from 2000 to 2019. In turn, there are 395 documents published by the researchers from the United Kingdom. It is worth noting that the scientists from the EU countries paid significantly less attention to exploring customer loyalty to banking. In turn, the most documents were published by researchers from Germany - 124 studies, Spain - 75, the Netherlands - 74, Italy - 70, France - 65, Sweden -55, etc.

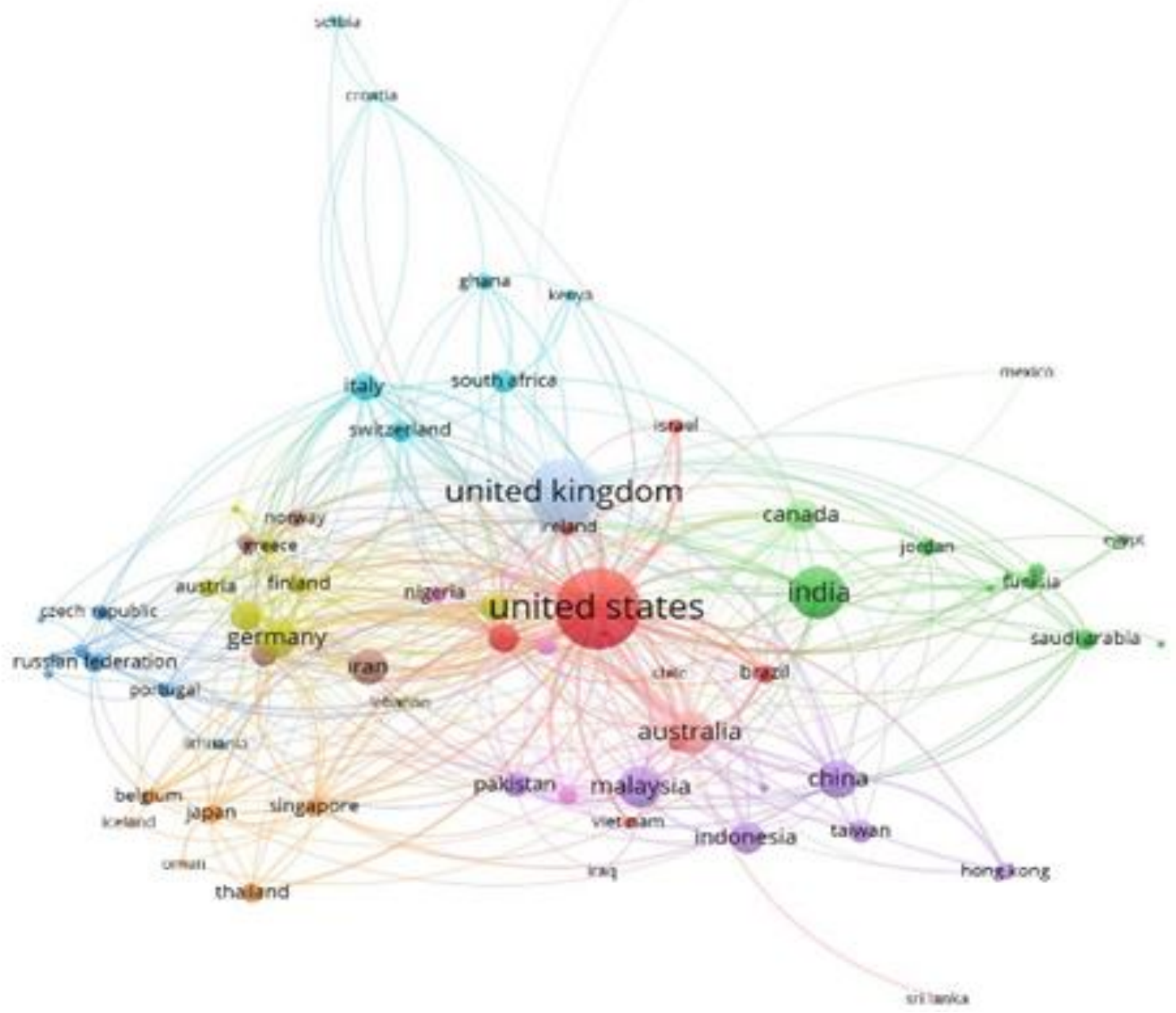

Figure 4. The Network Map of Co-authorship of Investigated Documents by the Countries (from 2000 to 2019).

Source: developed by the authors using the software VOSviewer 1.6.15 and the Scopus database.

The obtained results of the bibliometric analysis have indicated that the researchers with the USA affiliation have published the most significant number of scientific papers. Moreover, the visualization of co-authorship of the papers investigated (Figure 4) allowed demonstrating the scientific schools investigating the loyalty of bank customers. Given that, it proved the built 
hypothesis of this investigation that the scientific school of behavioral economics were formulated in the USA. In turn, according to Figure 4, the US researchers mostly collaborated with those from the United Kingdom, India, Canada, Australia, etc.

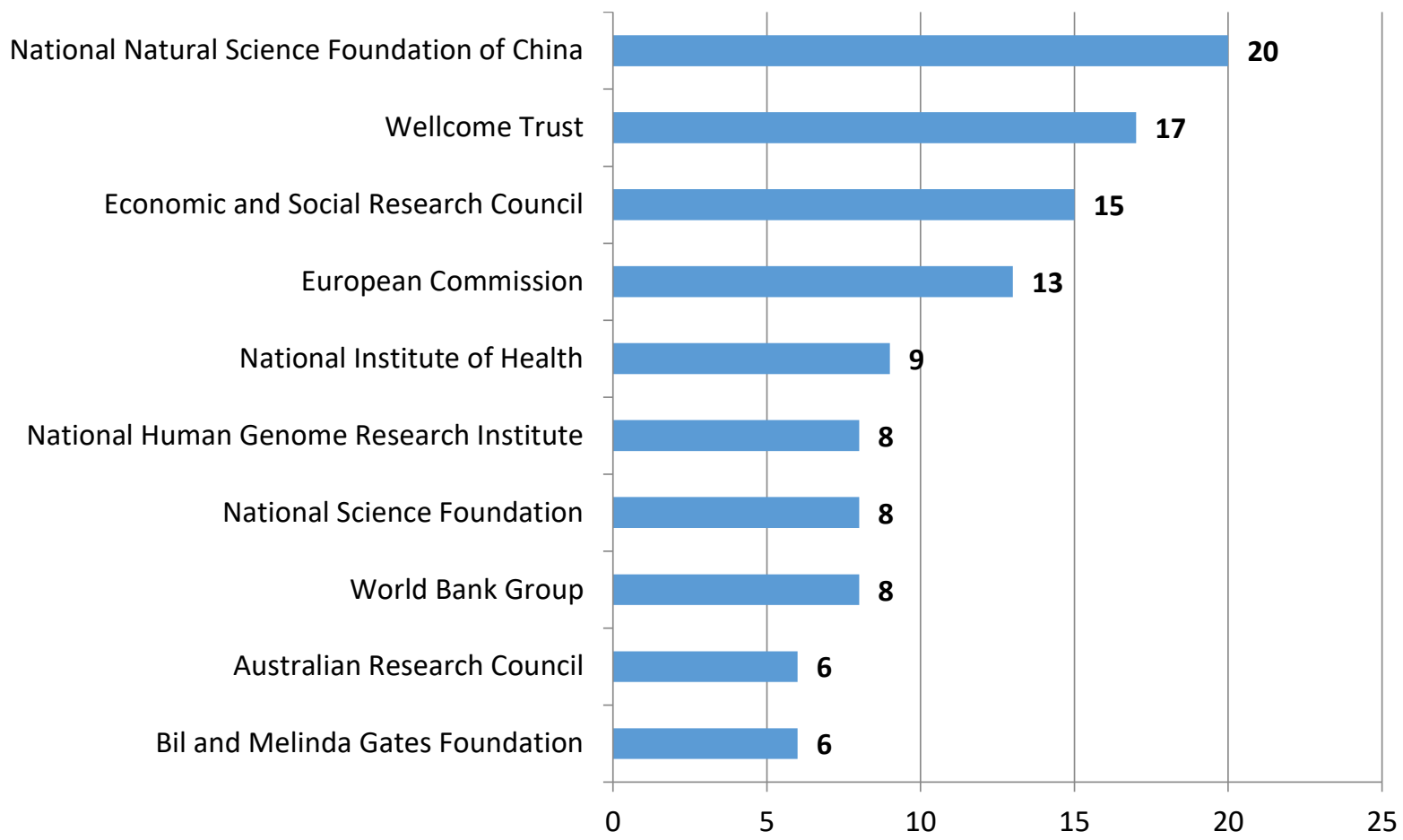

Figure 5. The Top-10 Funding Sponsors of Papers on Customer Loyalty to Banks (from 2000 to 2019).

Source: developed by the authors based on the Scopus data.

However, the analysis findings of the main funding sponsors of investigated documents suggested that the National Natural Science Foundation of China was a leader in financing scientific research on customer loyalty and bank reputation. Furthermore, its collaboration with foreign partners provided the research experience and a tendency of concept development on the customer loyalty across the world. It is worth indicating that the World Bank was in the TOP-10 funding sponsors. Consequently, it proved the hypothesis of the bank concernment on analyzing the behavior of bank customers (Fig. 5). Based on the obtained results it was found that the research investigated the issue of the customer loyalty to banking sector from the different points of view, such as: marketing, psychological, economic, financial, etc.

The bibliometric analysis findings allowed pinpointing five clusters combining the keywords by thematic relationship. In turn, the most used keyword proves to be "trust", which belongs to the first cluster and has 614 citations (Fig. 6). The most significant cluster (red) may be notionally named an "Impact factor of trust". This cluster consists of scientific papers focused on exploring the main determinants of customer behavior and trust, among which are: onlinebanking, finance crisis, safety, electronic commerce, etc. The second cluster (green) was 
named "Social and ethical". Thus, this cluster demonstrated scientific papers on the psychological aspects of customer behavior, analysis of the ethical issues of bank services in the medical sector, particularly medical insurance. The third cluster, named "Methodological", mostly included the scientific works presenting the methods used to investigate customer loyalty. Thus, prevalently the researchers applied the methods as follows: a questionnaire survey, scientific analysis of literature resources, systematization, etc.

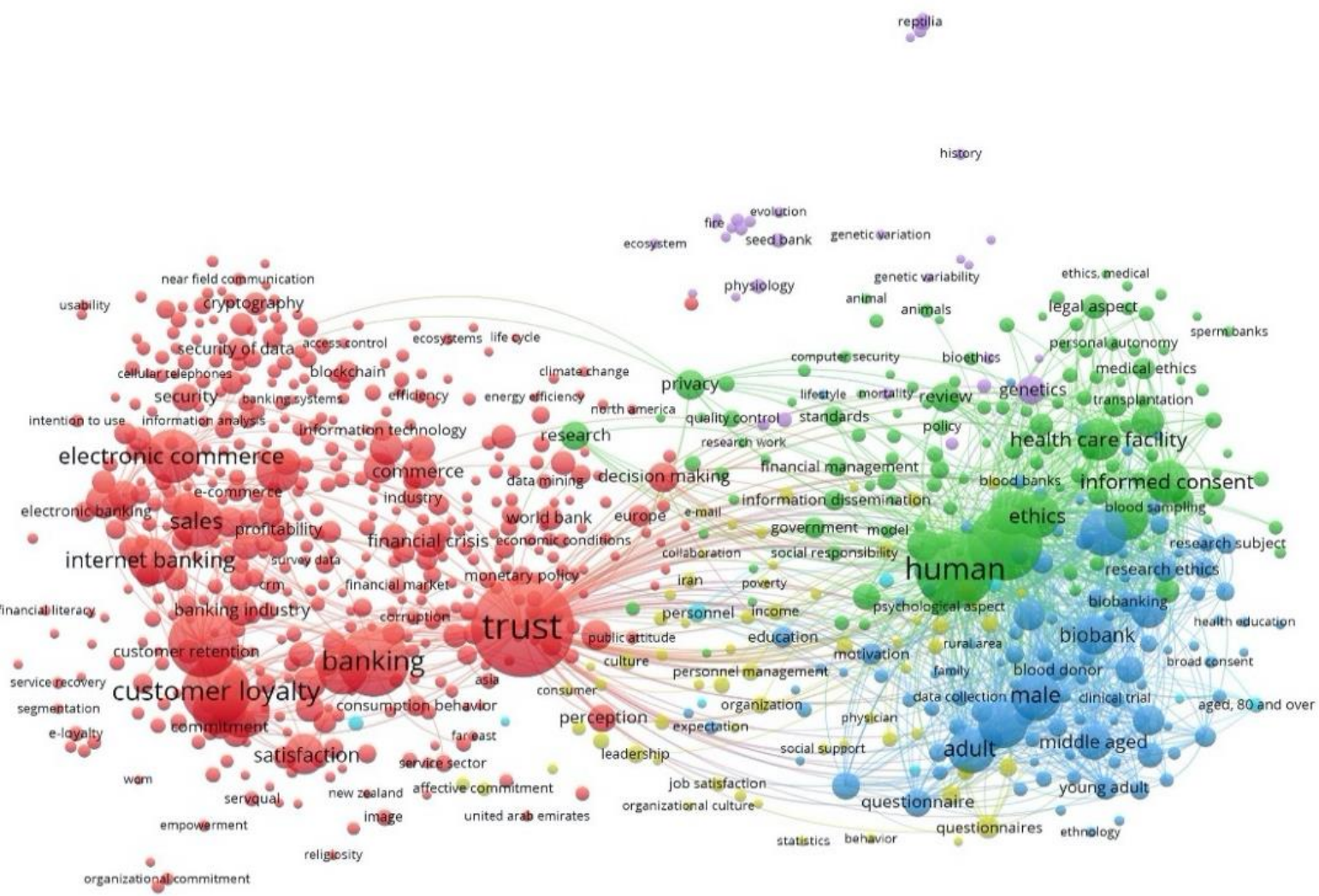

Figure 6. The Network Map Visualisation of Keywords Co-Occurrence of Investigated Documents (from 2000 to 2019).

Source: developed by the authors using the software VOSviewer 1.6.15 and the Scopus database.

The in-depth analysis of the most significant cluster (red) allowed identifying 438 links among the keywords. Herewith, the keywords which had the greatest number of links were banking, customer satisfaction, customer loyalty, the Internet, service quality, electronic commerce. Moreover, the detailed exploring of this cluster named an "Impact factor of trust" combines the different bank tendencies and innovative technologies.

First, it can be clearly seen that one of the most important factors was using the internet technology in the bank, which is connected with the Internet-banking, electronic commerce, customer demand satisfaction, etc. In view of that, it proved the thesis on the appropriateness of digitalizing the bank services. Furthermore, the next significant factor was the direct satisfaction of customers' needs. Indeed, the banks must be universal and offer a wide spectrum of services and opportunities. After that, the third significant impact factor of trust 
was the service level. Besides, the level of safety, privacy, protection of the customer operations were among the significant factors. In this case, it is worth noting that the considerable impact is made by the level of technology development to the point of mobile banking, the possibility to manage and perform the bank functions using the mobile application, etc.

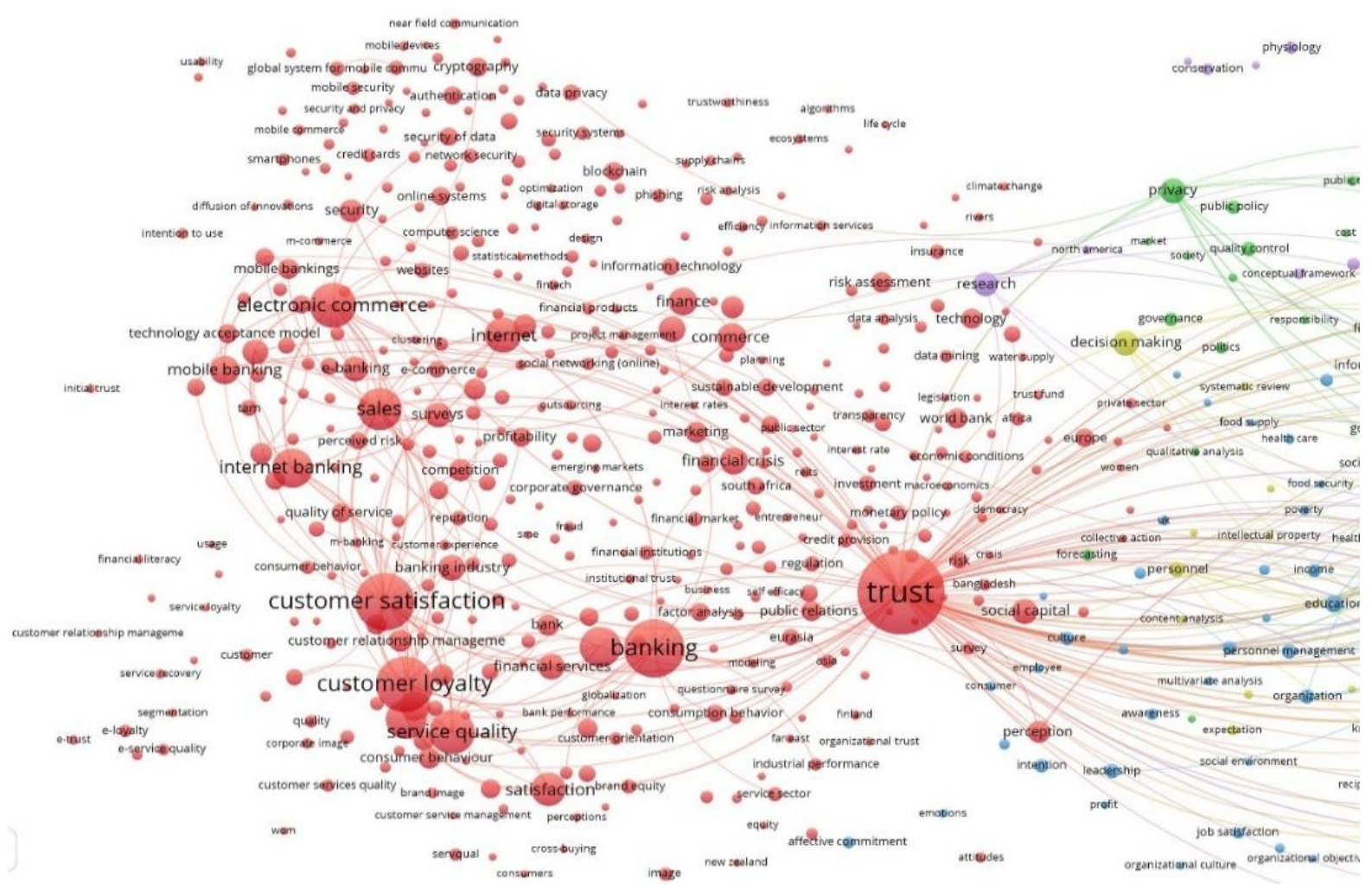

Figure 7. The Itemisation of the Keywords Co-Occurrence of the Red Cluster an "Impact Factor of Trust".

Source: developed by the authors using the software VOSviewer 1.6.15 and the Scopus database.

It should be emphasized that the keyword "banking" belonged to the red cluster and has 287 links. This keyword is mostly connected with the keywords as follows: trust, customer satisfaction, customer loyalty, electronic commerce, service quality, etc. (Fig. 8).

The second cluster, named "Social and ethical" had 122 links. Herewith, it has to be noted that the keywords humans, priority journal, ethic, health care facility, informed consent, biobank, access to information, policy, etc. had the greatest number of links (Fig. 9). 


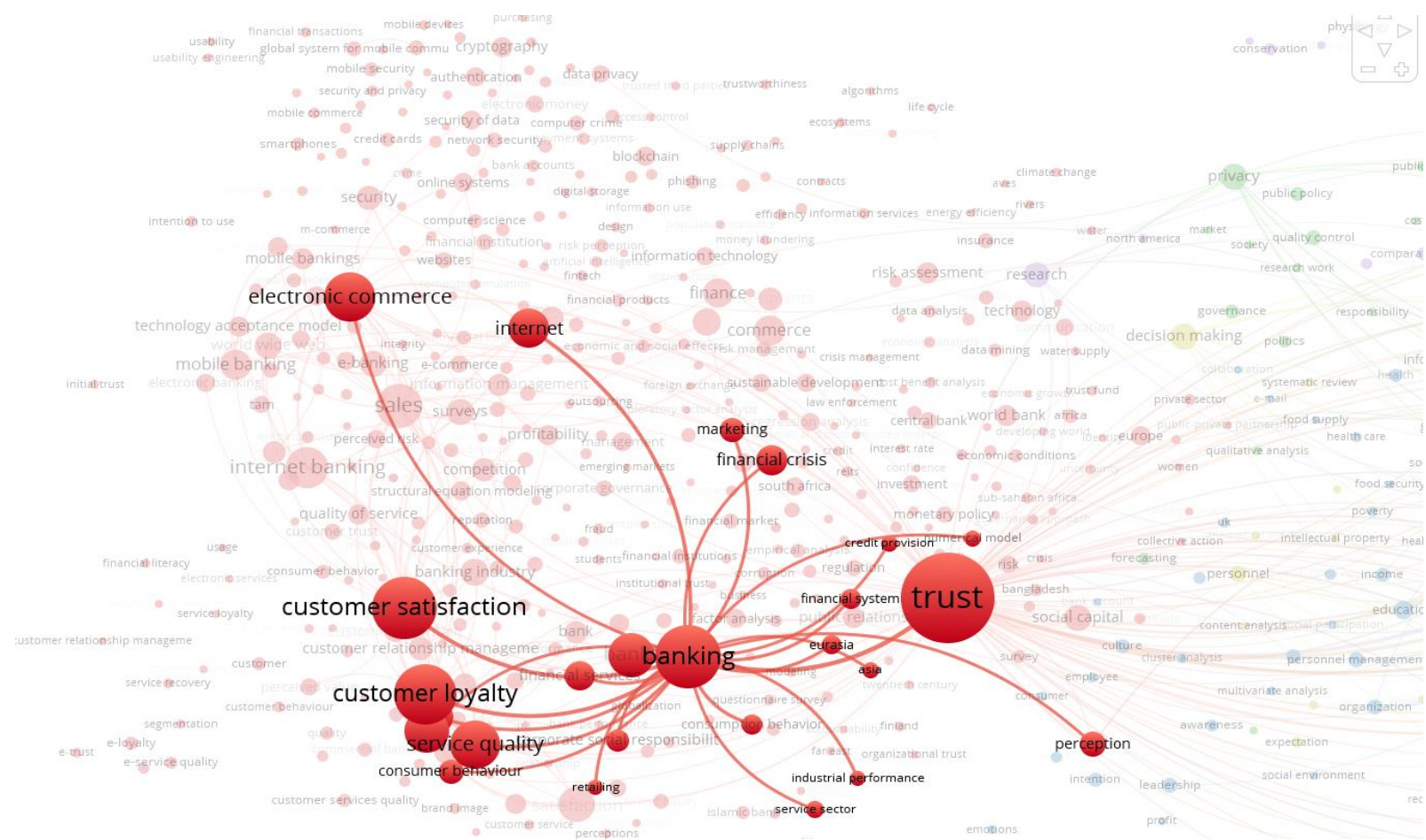

Figure 8. Visualising the Links of the Keyword "Banking" in the Red Cluster "Impact Factor of Trust".

Source: developed by the authors using the software VOSviewer 1.6.15 and the Scopus database.

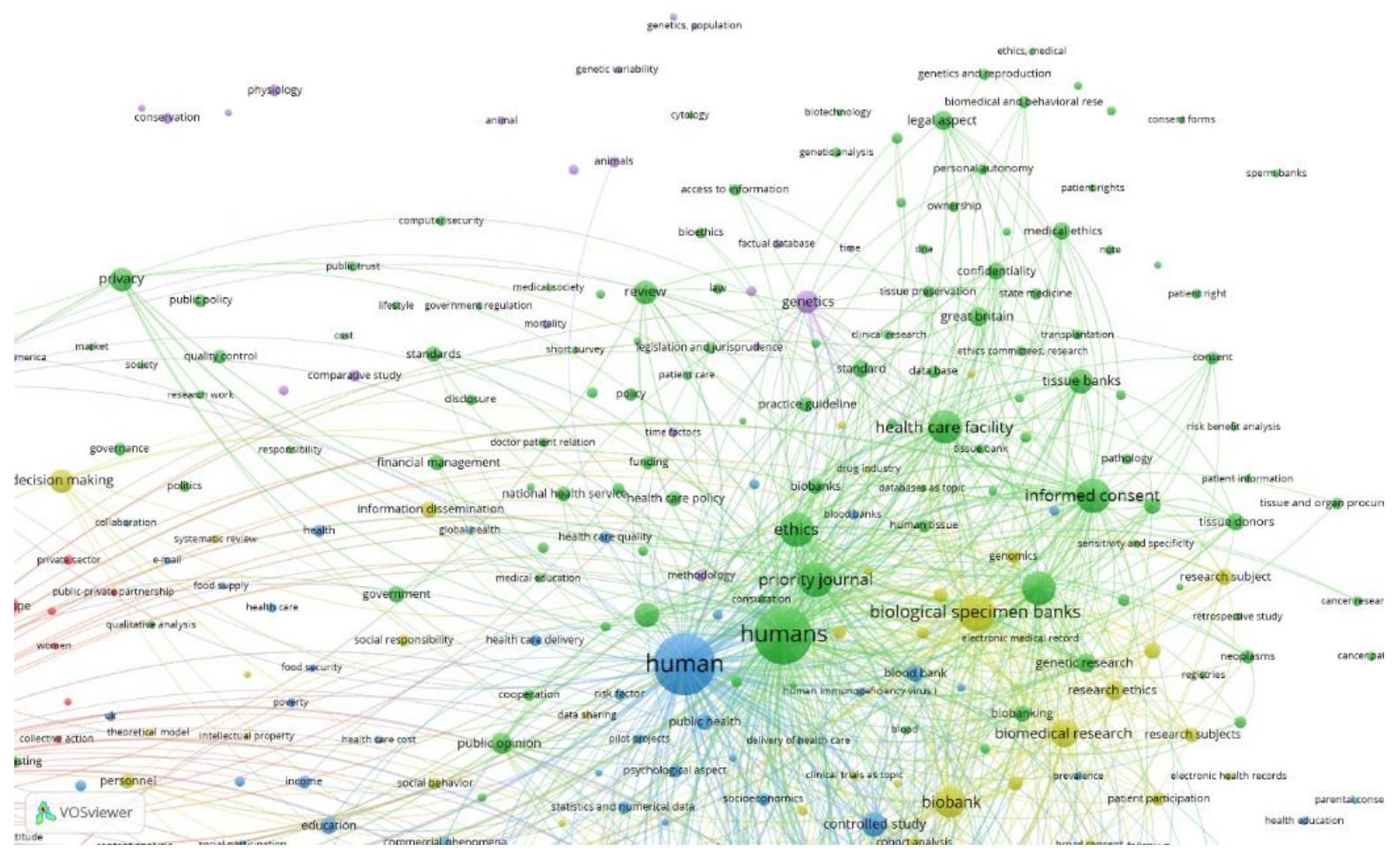

Figure 9. The Itemisation of the Keywords Co-Occurrence in the Green Cluster "Social and Ethical"

Source: developed by the authors using the software VOSviewer 1.6.15 and the Scopus database. 
Figure 10 demonstrates the relationship among the keywords of the third (blue) cluster named. In turn, there were 122 links among the presented keywords (Fig.10). The detailed analysis of the cluster's links allowed suggesting the scientists' investigation in the field of relationship between consumer loyalty and gender and age aspects. It can be clearly seen that the authors of those studies generally investigated the consumer behavior change depending on gender and age using the methodological tools like questionnaires, surveys, controlled studies etc. Herewith, the results of that study can be useful in building the communication strategy with customers of different age and gender.

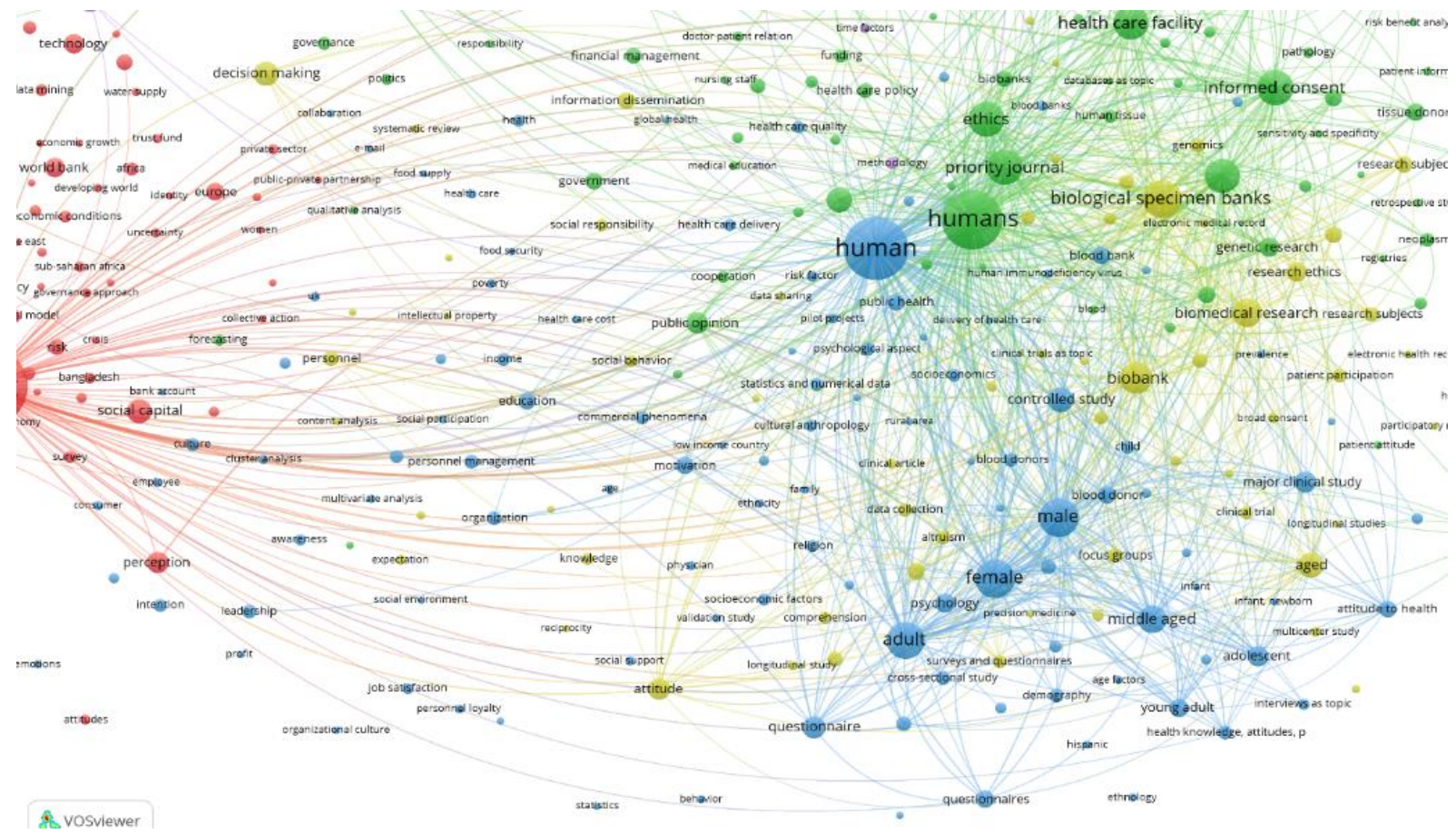

Figure 10. The Itemisation of the Keywords Co-Occurrence of the Blue and Yellow Clusters. Source: developed by the authors using the software VOSviewer 1.6.15 and the Scopus database.

The fourth yellow cluster combines 61 items aimed at investigating the field of biological patterns, biological specimen banks, biomedical research, biological studies, etc. According to Figure 10, it is to be noted that this cluster had a strong relationship with the second "Social and Ethical" and the third "Methodological" clusters. In turn, the smallest cluster consists of 40 items where the main focus was on psychology, evolution, population, ecosystem, etc.

\section{Conclusions}

The obtained results of the current research proved that the issues on bank institutions' reliability and customer loyalty were always urgent. Herewith, the publication activity has a positive tendency. Moreover, the emerging financial crises cause new challenges to appear in the bank sector and boost the growth of researchers' interest. Furthermore, the findings allowed highlighting the several scientific schools investigating the issues on customer loyalty 
to banks, the American one being the largest. Herewith, the terminological network maps provided five clusters demonstrating the considered aspects of the investigated theme. Summarizing conclusions of the scientific papers involved, it was clear that the level of customer loyalty to banks institutions depended on their reputation, service quality, credibility, gender and age aspects, etc. Thus, the findings of the current research on the bibliometric analysis might be the base for future investigation on developing the communication strategies to increase customer loyalty to bank institutions.

\section{Sources of Funding}

This research was funded by the grant from the Ministry of Education and Science of Ukraine (no. 0117U003932; no. 0118U003569).

\section{References}

Aurier, P., \& N'Goala, G. (2010). The Differing and Mediating Roles of Trust and Relationship Commitment in Service Relationship Maintenance and Development. Journal of the Academy of Marketing Science, 38(3), 303-325. https://doi.org/10.1007/s11747-009-0163-z

Baumann, C., Burton, S., Elliott, G., \& Kehr, H. M. (2007). Prediction of Attitude and Behavioural Intentions in Retail Banking. International Journal of Bank Marketing, 25(2), 102-116. https://doi.org/10.1108/02652320710728438

Bilan, Y., Vasilyeva, T., Lyulyov, O., \& Pimonenko, T. (2019). EU Vector of Ukraine Development: Linking Between Macroeconomic Stability and Social Progress. International Journal of Business and Society, 20(2), 433-450.

Bloemer, J., de Ruyter, K., \& Peeters, P. (1998). Investigating Drivers of Bank Loyalty: The Complex Relationship between Image, Service Quality and Satisfaction. International Journal of Bank Marketing, 16(7), 276-286. https://doi.org/10.1108/02652329810245984

Casaló, L. V., Flavián, C., \& Guinalíu, M. (2008). The Role of Satisfaction and Website Usability in Developing Customer Loyalty and Positive Word-Of-Mouth in the E-Banking

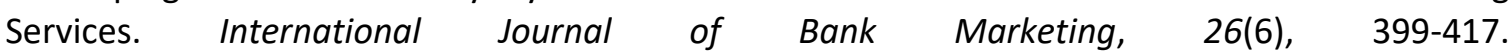
https://doi.org/10.1108/02652320810902433

Chygryn, O., Pimonenko, T., Luylyov, O., \& Goncharova, A. (2018). Green Bonds like the Incentive Instrument for Cleaner Production at the Government and Corporate Levels Experience from EU to Ukraine. Journal of Environmental Management and Tourism, 9(7), 1443-1456. https://doi.org/10.14505//jemt.v9.7(31).09

Chigrin, O., \& Scherbak, A. (2011). Analiz problemy vprovadzhennya ekolohichno chystoho vyrobnytstva $\vee$ Ukrayini [Analysis of the Main Problems of Ecologically Pure Production Implementation in Ukraine]. Mechanism of Economic Regulation, 1, 235-241. [in Ukrainian].

Cooil, B., Keiningham, T. L., Aksoy, L., \& Hsu, M. (2007). A Longitudinal Analysis of Customer Satisfaction and Share of Wallet: Investigating the Moderating Effect of Customer Characteristics. Journal of Marketing, 71(1), 67-83. https://doi.org/10.1509/jmkg.71.1.67 
Dzwigol, H., Dzwigol-Barosz, M., Miskiewicz, R., \& Kwilinski, A. (2020). Manager Competency Assessment Model in the Conditions of Industry 4.0. Entrepreneurship and Sustainability Issues, 7(4), 2630-2644. https://doi.org/10.9770/jesi.2020.7.4(5)

Han, X., Kwortnik Jr., R. J., \& Wang, C. (2008). Service loyalty: An Integrative Model and Examination across Service Contexts. Journal of Service Research, 11(1), 22-42. https://doi.org/10.1177/1094670508319094

Ibragimov, Z., Lyeonov, S., \& Pimonenko, T. (2019). Green Investing for SDGS: EU Experience for Developing Countries. In: Proceedings of the 37th International Scientific Conference on Economic and Social Development "Socio Economic Problems of Sustainable Development", February 14-15 (pp. 868-877). Baku: Azerbaijan State University of Economics.

Jones, M. A., Mothersbaugh, D. L., \& Beatty, S. E. (2002). Why Customers Stay: Measuring the Underlying Dimensions of Services Switching Costs and Managing their Differential Strategic Outcomes. Journal of Business Research, 55(6), 441-450. https://doi.org/10.1016/S01482963(00)00168-5

Kwilinski, A. (2019). Implementation of Blockchain Technology in Accounting Sphere. Academy of Accounting and Financial Studies Journal, 23(SI2), 1-6.

Kwilinski, A., Dzwigol, H., Dementyev, V. (2020). Model of Entrepreneurship Financial Activity of the Transnational Company Based on Intellectual Technology. International Journal of Entrepreneurship, 24(Special Issue), 1-5.

Loveman, G. W. (1998). Employee Satisfaction, Customer Loyalty, and Financial Performance: An Empirical Examination of the Service Profit Chain in Retail Banking. Journal of Service Research, 1(1), 18-31. https://doi.org/10.1177/109467059800100103

Lyulyov, O. V., \& Pimonenko, T. V. (2017). Model' Lotky-Vol'terry yak instrument analizu stiykosti investytsiynykh ta innovatsiynykh protsesiv [Lotka-Volterra Model as an Instrument of the Investment and Innovative Processes Stability Analysis]. Marketing and Management of Innovations, 1, 159-169. https://doi.org/10.21272/mmi.2017.1-14 [in Ukrainian].

Lyulyov, O., \& Shvindina, H. (2017). Stabilisation Pentagon Model: Application in the Management at Macro- and Micro-Levels. Problems and Perspectives in Management, 15(3), 42-52. https://doi.org/10.21511/ppm.15(3).2017.04

Matsenko, O., Chigrin, E., Taranovsky, V., Dolgodush, A. (2011). Sotsio-ekoloho-ekonomichni problemy vodopostachannya v Ukrayini [Socio-Ecological-Economic Challenges of Water Supply in Ukraine]. Mechanism of Economic Regulation, 4, 264-271. [in Ukrainian].

Matute-Vallejo, J., Bravo, R., \& Pina, J. M. (2011). The Influence of Corporate Social Responsibility and Price Fairness on Customer Behaviour: Evidence from the Financial Sector. Corporate Social Responsibility and Environmental Management, 18(6), 317-331. https://doi.org/10.1002/csr.247

Pająk, K., Kamińska, B., \& Kvilinskyi, O. (2016). Modern Trends of Financial Sector Development under the Virtual Regionalization Conditions. Financial and Credit Activity: Problems of Theory and Practice, 2(21), 204-217. https://doi.org/10.18371/fcaptp.v2i21.91052

Panchenko, V., Harust, Yu., Us, Ya., Korobets, O., \& Pavlyk, V. (2020). Energy-Efficient Innovations: Marketing, Management and Law Supporting. Marketing and Management of Innovations, 1, 256264. http://doi.org/10.21272/mmi.2020.1-21 
Sweeney, J., \& Swait, J. (2008). The Effects of Brand Credibility on Customer Loyalty. Journal of Retailing and Consumer Services, 15(3), 179-193. https://doi.org/10.1016/j.jretconser.2007.04.001

Tkachenko, V., Kwilinski, A., Korystin, O., Svyrydiuk, N., \& Tkachenko, I. (2019). Assessment of information technologies influence on financial security of economy. Journal of Security and Sustainability, 8(3), 375-385. http://doi.org/10.9770/jssi.2019.8.3(7)

Vishnevsky, V.P., \& Kwilinski, A. (2019). Recent Trends in US Monetary Policy and Its Influence on Economic Development: An Analytical Review. Economy of Industry, 3(87), 125-142.

Oleksii Dubina, Yana Us, Tetyana Pimonenko, and Oleksii Lyulyov

Virtual Economics, Vol. 3, No. 3, 2020 